\title{
OCCURRENCE, ECOLOGY AND PHYLOGENY OF BANANA STREAK BADNAVIRUS (BSV) AND CUCUMBER MOSAIC CUCUMOVIRUS (CMV) IN MUSA SP. PRODUCTION AREAS OF THE MEDITERRANEAN COASTLINE OF TURKEY
}

\author{
FIDAN, $\mathrm{H}^{1 *}-\mathrm{KOÇ}, \mathrm{G}^{2}$ \\ ${ }^{I}$ Plant Protection Department, Faculty of Agriculture, Akdeniz University, \\ 07070, Antalya, Turkey \\ ${ }^{2}$ Subtropical Fruits Research and Experimental Center, Çukurova University, Adana, Turkey \\ *Corresponding author \\ e-mail: hakanfidantr@hotmail.com.tr
}

(Received 31 ${ }^{\text {st }}$ Jan 2019; accepted 6 ${ }^{\text {th }}$ Mar 2019)

\begin{abstract}
The Banana infecting viruses have an importance in the movement and propagation of plant germplasm, especially in areas where banana is propagated vegetatively. During field surveys 118 banana leaf samples have been tested by DAS-ELISA, PCR and RT-PCR have shown malformation, necrosis, chlorotic streak and mosaic symptoms collected from Mediterranean Coast Line (Adana, Antalya and Mersin provinces) of Turkey in 2015 and 2016. For diagnosis of CMV, BBTV, BSV, TMV, PVY, WMMV, PRSV, BCMV and TSWV pathogens that cause severe crop loss in banana plantations firstly, serological tests have been conducted using DAS-ELISA immune kit. Further identification and confirmation studies by PCR and RT-PCR from leaf samples exhibiting mild chlorotic streaks and mosaics on leaves, typical infection of Banana streak mosaic virus (BSV) and Cucumber mosaic cucumovirus (CMV) were used. Their symptoms were truly matched in PCR (BSV \& CMV) and DASELISA (CMV) analyses. Disease incidence was consequently estimated between $17.79 \%$ (CMV) and 4.23\% (BSV). This is the first molecular evidence for BSV or BSV mixed with CMV in banana in Turkey. Sequence information of PCR products were obtained from Hoplotypes and searched on BLAST system of NCBI. Phylogenetic analyses have informed the origin and ecology of CMV in bananas which were infected by vegetables grown inside the banana greenhouses The banana BSV isolate was in the same group isolates that were obtained in Kenya, Congo, Australia, China and India.
\end{abstract}

Keywords: molecular ecology of banana viruses, BSV, CMV, PCR, DAS-ELISA

\section{Introduction}

Banana (Musa spp.) is an economically important fruit, which is grown in tropical and subtropical climates and are widely consumed in both fresh and preserved form. Production is not only concentrated in the Mediterranean area of Turkey, but it is also produced worldwide (FAO, 2015). Around the world, roughly 145 million tons of bananas are grown each year (Baggaley, 2017). In Turkey according to the Ministry of Food, Agriculture and Livestock, 369009 tons of banana fruit was produced at the Mediterranean Coast Line (Adana, Mersin and Antalya provinces) in 2017. Additionally, an increase (14.4\%) in banana production has been forecasted for this year (TUIK, 2017). There are many factors decreasing the quantity and quality of banana production more likely than in other fruit crops. One of the most important restrictive factors including plant diseases and pests, are viral agents. Among the important agronomic traits, virus resistance is one of the major breeding objectives, as several diseases caused by viruses have great economic impact on production. 
Banana bunchy top virus (BBTV), Banana streak virus (BSV), Cucumber mosaic virus (CMV), Banana bract mosaic virus (BBrMV), Banana mild mosaic virus (BanMMV), Banana virus X (BVX) are major banana infecting viral agents (Tripathi et al., 2016). Morphology, taxonomy, symptomatology, cytopathology, epidemiology, diagnosis and sanitation of these Musa spp infecting species were reviewed by Teycheney and Lescot (2004). Furthermore, Water melon mosaic virus, Papaya ringspot virus, Tobacco mosaic virus, Bean common mosaic virus, Tomato spotted wilt virus, Potygroup and Potato virus $Y$ could cause diseases in bananas. Nevertheless, based on the symptoms observed, Gambley and Thomas, (2001) has been underlined some viral infections.

Banana buncy top virus was first recorded in Fiji in 1889, and has spread broadly in banana production areas. It has been transmitted by sucker, and black aphid (Pentalonia nigronervosa). Also tissue culture propagation has an importance on transmission, due to noneradicated infections. The Banana buncy top virus can cause major economic yield loss. Another major threat is Banana streak virus that can cause leaf streak disease, it is a member of genus Badnavirus, and was first recorded in 1986. There are two main distinct strains of BSV (Lockhart and Olszewski, 1993). The Onne strain of BSV, now renamed BSV-OL (R Hull, personal communication), in Africa, Central and South America. The other strain is called as the Cavendish strain of BSV (BSV-Cav), which has been found in commercial banana plantations in Australia. BSV is transmitted by Planococcus citri (Risso) and possibly other species of mealybug (Lockhart and Jones, 1999). The characteristic symptoms of BSV infection are mainly chlorotic and necrotic streaks on the leaves. Other symptoms may include narrowing and thickening of the leaf, internal pseudostem necrosis, splitting of the base of the leaf sheaths and detachment of leaves, overall stunting of the plant, smaller bunches and abnormally shaped fruit with a thinner peel that is prone to splitting. The symptoms are probably diverged by factors such as environmental conditions, and host and virus genotypes (Lockhart and Jones, 1999).

BSV is transmitted by infected mother plants and through tissue-culture propagation of infected explants and by several mealybug (Hemiptera: Coccoidea: Pseudococcidae) species, but not mechanically (Lockhart and Jones, 1999). Mealybug species which have been confirmed as vectors include the citrus mealybug, Planococcus citri Russo (Lockhart and Olszewski, 1993), Pseudococcus comstiki Kuwana (Su, 1998), both the pineapple mealybug Dysmicoccus brevipes Cockerell and the sugarcane mealybug Sacchirococcus sacchari Cockerell (Kubiriba et al., 2001b), and the vine mealybug Planococcus ficus Signoret (Meyer et al., 2008).

Sison et al. (2017) underlined that BSV can be transmitted to uninfected banana by mealybugs of Musa sp. (Pseudo-coccus elisae and Dysmicoccus brevipes), Manilkara zapota (unreported), Anonna muricata, Ananas comosus (Dysmicoccus brevipes) and Nephelium napaceum. Infection transmission proficiency and mean effect seriousness was eminently most astounding utilizing the vectors from the last two yields. Mealybugs assume a noteworthy job in the characteristic spread of the infection. Since bananas in the Philippines are likewise planted close by the previously mentioned harvests, the board systems ought to tend to decrease the number of inhabitants in these mealybug species from fields.

The prevalent infection by CMV (Cucumovirus), has been classified by serology and symptomology (mosaic, line patterns and ringspot at leaf), and has three subgroups (IA, $\mathrm{Ib}$ and II) regarding coat protein gene. Interveinal chlorosis is also caused by CMV 
strains. If strain severity is higher, plant mortality may become by CMV infections. CMV has been transmitted by sucker, and aphids. Eradication, certified material and vector management are important strategies to overcome the menace. CMV has many host species even ornamentals in Turkey (Koç. et al., 2016; Karanfil et al., 2016)

The aims of the paper are to determine the presence and distribution of common banana viruses, including BSV, BBTV and CMV in the Mediterranean Area of Turkey. Existence of banana viruses has not yet been explored by reliable* laboratory assays (i.e. more sensitive current techniques for detection and characterization such as serological (DAS-ELISA) and molecular (PCR) methods) other than those used in this study in our country.

\section{Materials and methods}

The research was conducted in the Mediterranean Coast Line of Turkey in 20152016 years. A total of 118 samples were collected from suspected plants in banana plantains at different locations in the line. During the surveys, small and shapeless malformed leaves, light colored areas resembling mosaic with streaks of necrotic areas of the leaves and small bunchy formations were observed on plants. Surveys were conducted during the growing season and only symptomatic samples were collected randomly throughout the area in Turkey (Fig. 1).

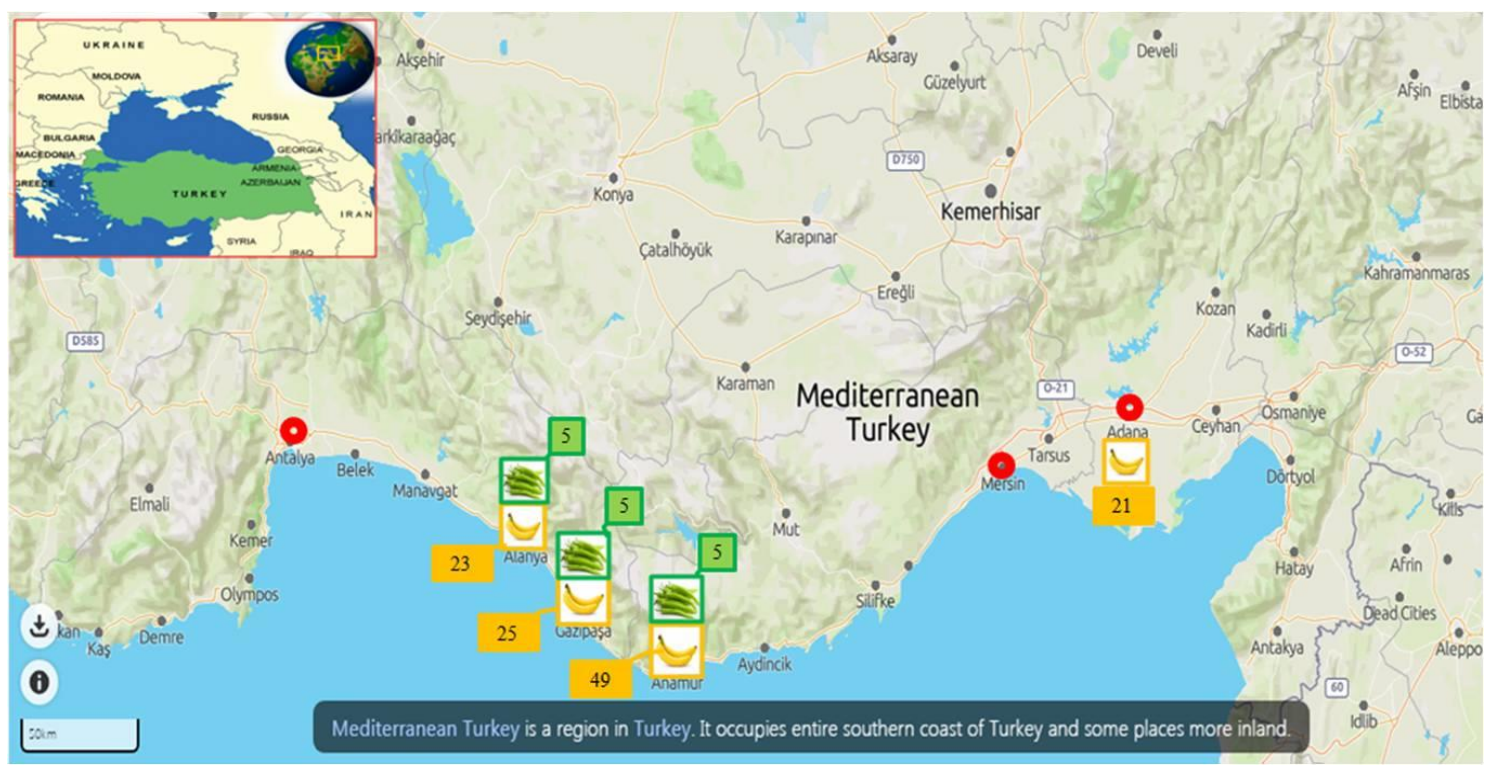

Figure 1. Origin and number of samples per site from sampling area. (https://www.countryreports.org/travel/Turkey.html; https://mapcarta.com/Mediterranean_Turkey/Map)

Green pepper plants, has been sampled which are grown for non commercial purposes at suitable places of the banana plantations. The typical symptom showing banana and pepper plants PCR product used for analyses. 


\section{Serological tests}

The samples, were labelled and placed in separate plastic bags, they were brought to the Virology Laboratory placed in ice bucket and kept at $4{ }^{\circ} \mathrm{C}$. All samples were processed within $24 \mathrm{~h}$.

\section{Double antibody sandwich enzyme linked immunosorbent assay (DAS-ELISA)}

For the identification of viruses infecting Musa spp., leaf samples were tested by DAS-ELISA using polyclonal antiserum specific to the following viruses: BBTV (Banana bunchy top virus), CMV (Cucumber mosaic cucumovirus), TMV (Tobacco mosaic tobamovirus), TSWV (Tomato spotted wilt orthotospovirus), PVY (Potato Y potyvirus), BCMV (Bean common mosaic potyvirus), WMV-2 (Watermelon mosaic 2 potyvirus), PRSV (Papaya ringspot virus) Potygroup and Orthotospovirus Etc. specific antisera purchased from Agdia USA, Bioreba AG, Switzerland and Loewe ${ }^{\circledR}$ Biochemica GmbH, Germany, respectively.

Tests involved detection of viruses in infected young leaves and were carried out according to Clark and Adams (1977). Polystyrene microtiter plates were coated with 1:200 dilution of gamma globulin. The leaves of infected young plants were grounded in the extraction buffer (phosphate buffered saline, PBS, pH 7.0). Plant samples were applied at a dilution of $1 / 5$ (Wff) in PBS ( $\mathrm{pH} 7.0$ ), containing 0.05 volumes Tween-20, $0.2 \%$ polyvinyl pyrolidone (PVP-40) and $2 \%$ bovine serum albumin (BSA). IgGconjugate was applied at the concentration of $1 \mathrm{ul} / 200 \mathrm{ul}$ (Agdia and Loewe) and $1 \mathrm{ul} / 1000 \mathrm{ul}$ (Bioreba). Alkaline phosphatase conjugate was used at a 1/1000 dilution.

Results were acquired spectrophotometrically at $405 \mathrm{~nm}$ wave length with a Medispec ESR 200 ELISA microplate reader. Also, negative controls (healthy samples), twice the mean value of healthy specimen were considered as positive. Positive controls of all viruses were supplied in lyophilized form with the kits and were resuspended in the sample buffer as recommended by the manufacturer (Agdia, Inc.).

\section{Total RNA isolation, reverse-transcription polymerase chain reaction (RT-PCR) and phylogenetic analysis}

Total RNA extracts (Dellaporta et al., 1983) of BSV, CMV and BBTV suspected banana samples were used in a PCR and RT-PCR (Reverse-Transcription Polymerase Chain Reaction) with BSV5466 5'-AGAGTGGGTTTCATCAAGTAGC and primer BSV 6196 5'-GAATTTCCCGCTCGCATAAG). The primer number indicates $731 \mathrm{bp}$ positions (one cycle of $94{ }^{\circ} \mathrm{C}$ denaturation for $4 \mathrm{~min}, 30$ cycles each at $94{ }^{\circ} \mathrm{C}$ for $30 \mathrm{~s}$, gradient temp $58{ }^{\circ} \mathrm{C}$ for $30 \mathrm{~s}$ and $72{ }^{\circ} \mathrm{C}$ for $30 \mathrm{~s}$ followed by one cycle of final extension for $10 \mathrm{~min}$.) in the BSV genome (Cherian et al., 2004); partially 513 bp CMV CP genes were cloned by sense CMVf TAACCTCCCAGTTCTCACCGT and antisense CMVr CCATCACCTTAGCTTCCATGT primers $\left(95^{\circ} \mathrm{C}, 45 \mathrm{~s}\right.$; $52^{\circ} \mathrm{C}, 30 \mathrm{~s}$; and $72{ }^{\circ} \mathrm{C}, 45 \mathrm{~s}$ and final extension $72{ }^{\circ} \mathrm{C}$ for 10 min totally 35 cycles) according to Buzkan and Yüzer (2009); CP.F1 5'ATGGCTAGGTATCCGAAG 3' and CP.R1 5'CCAGAACTACAATAGAATGCC 3'primers, designed for BBTV virus indexing, were cloned partially $530 \mathrm{bp}$ (denaturation for $5 \mathrm{~min}$ at $94^{\circ} \mathrm{C}$, then 35 cycles of: $1 \mathrm{~min}$ at $94{ }^{\circ} \mathrm{C}, 1 \mathrm{~min}$ at $57{ }^{\circ} \mathrm{C}, 90 \mathrm{~s}$ at $72{ }^{\circ} \mathrm{C}$, and then a final extension for $10 \mathrm{~min}$ at $72{ }^{\circ} \mathrm{C}$.) by Mahadev et al. (2013). CP genes of each viruses have been subjected to processing at PCR thermocycler by using Thermo Scientific Verso 1-Step RT-PCR Hot-Start Kit according to manufacturer's protocol. 
Standard PCR for DNA viruses and RT-PCR for RNA viruses were used and total RNA was isolated from leaf tissue by the RNeasy Plant Mini Kit (Qiagen).

\section{Analysis of PCR products}

PCR reaction mixture (Ten microlitres) was combined with gel loading buffer and analyzed on a $1.5 \%$ agarose gel containing $0.5 \mathrm{mg} / \mathrm{ml}$ of ethidium bromide and photographed (Sambrook et al., 1989). 100 bp DNA ladder (thermo) or Bio Marker ${ }^{\mathrm{TM}}$ Low (Bio Ventures, Inc.) were used on each gel to determine the length of the amplified product. PCR-amplicons run at $100 \mathrm{~V}$ for 70 to $80 \mathrm{~min}$, and the gel was stained with ethidium bromide.

\section{Phylogenetic analysis}

The PCR products were obtained and directly sequenced by Commercially Sequencing Service. Sequences were compared via databank BLAST on NCBI server (www.ncbi, nlm.nih.gov). Dnasp5 program was conducted for diversification, genetic distance and neighbourhood analyses. According to these analyses, a phylogenetic tree has established by MEGA 7 Program and Neighbours joining method.

\section{Results}

\section{Type of symptoms}

Mosaic and chlorotic streaking along the veins of the leaves, leading to necrosis, are common.

Virus infected leaves in the fields reduced in size and light colored yellowish necrotic leaf margin areas resembling to mosaic with streaks occured (Fig. 2); There were also, leaf mosaics, necrotic streaks, small narrowed and shapeless malformated leaves (Fig. 3), bunchy head formation and general discoloration were observed on the plants (Fig. 4). Leaf mosaics, marginal necrosis on banana plants are shown in Fig. 5. During harvesting, the plant was cut from the beginning to the end of line. The agricultural worker has not changed or sterilized all cutting equipments. Therefore, all harvested plants could have shown severe disease symptoms. This is clearly indicated that mechanically harvesting will spread the viruses. 


$$
\text { - } 5940 \text { - }
$$

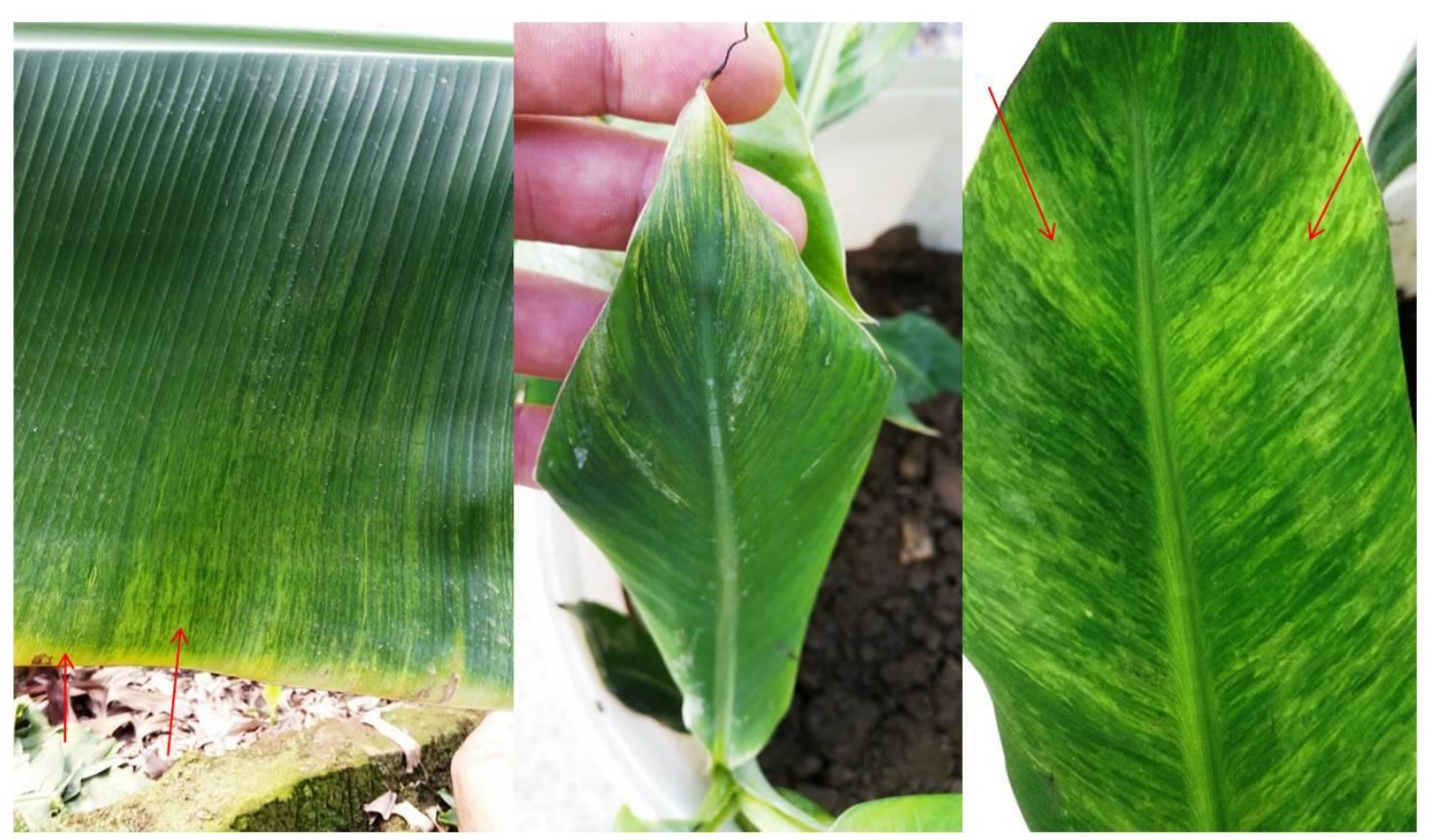

Figure 2. Light colored yellowish necrotic leaf margin areas resembling to streaks

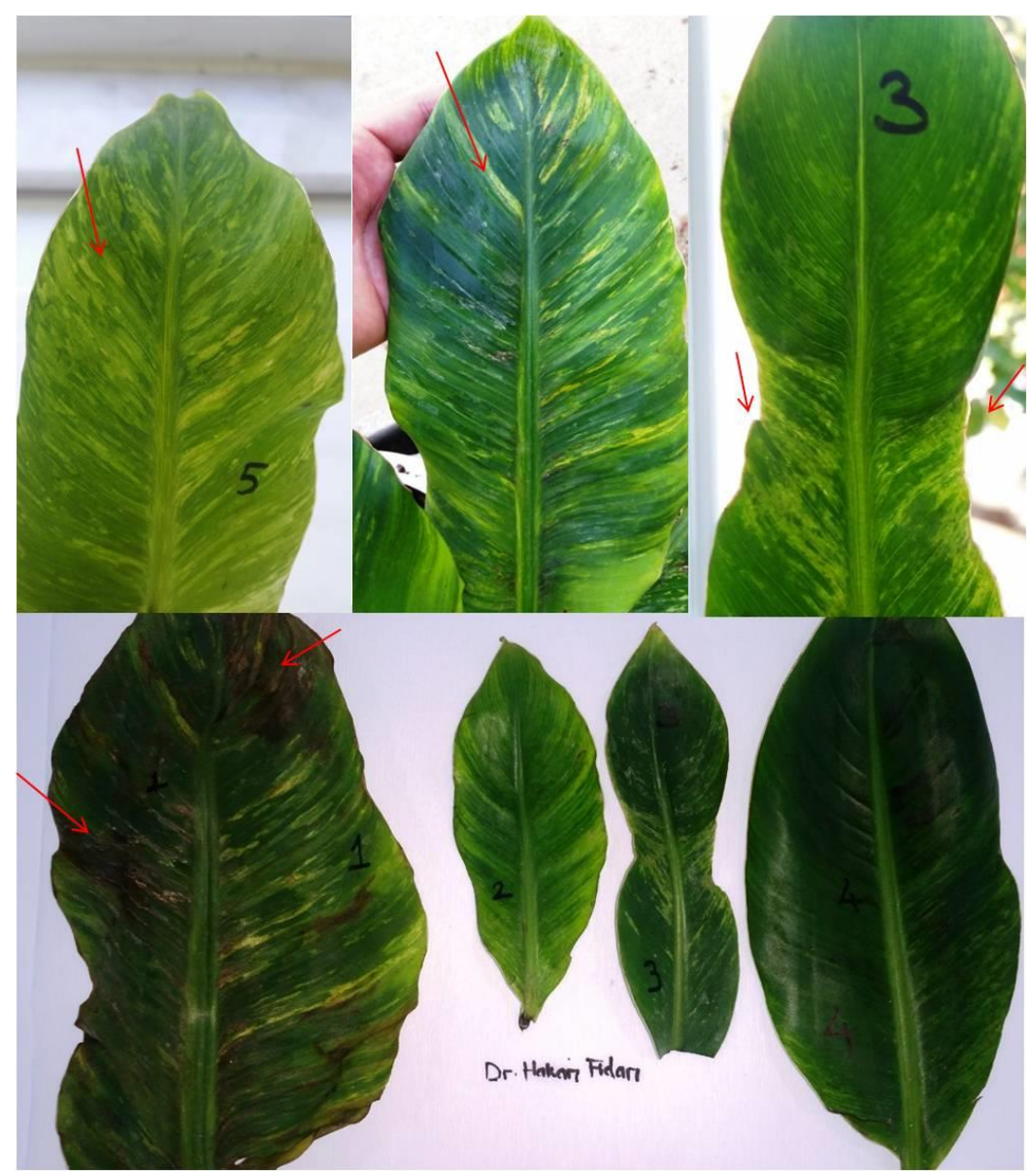

Figure 3. Leaf mosaics, necrotic streaks, mosaic, small narrowed and shapeless malformated leaves 


$$
\text { - } 5941 \text { - }
$$

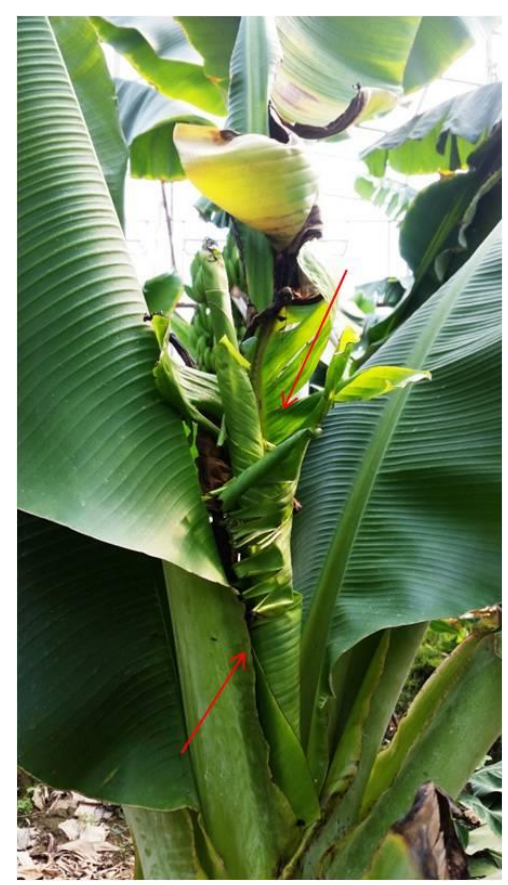

Figure 4. Small-bunchy formation and general discoloration on banana plants

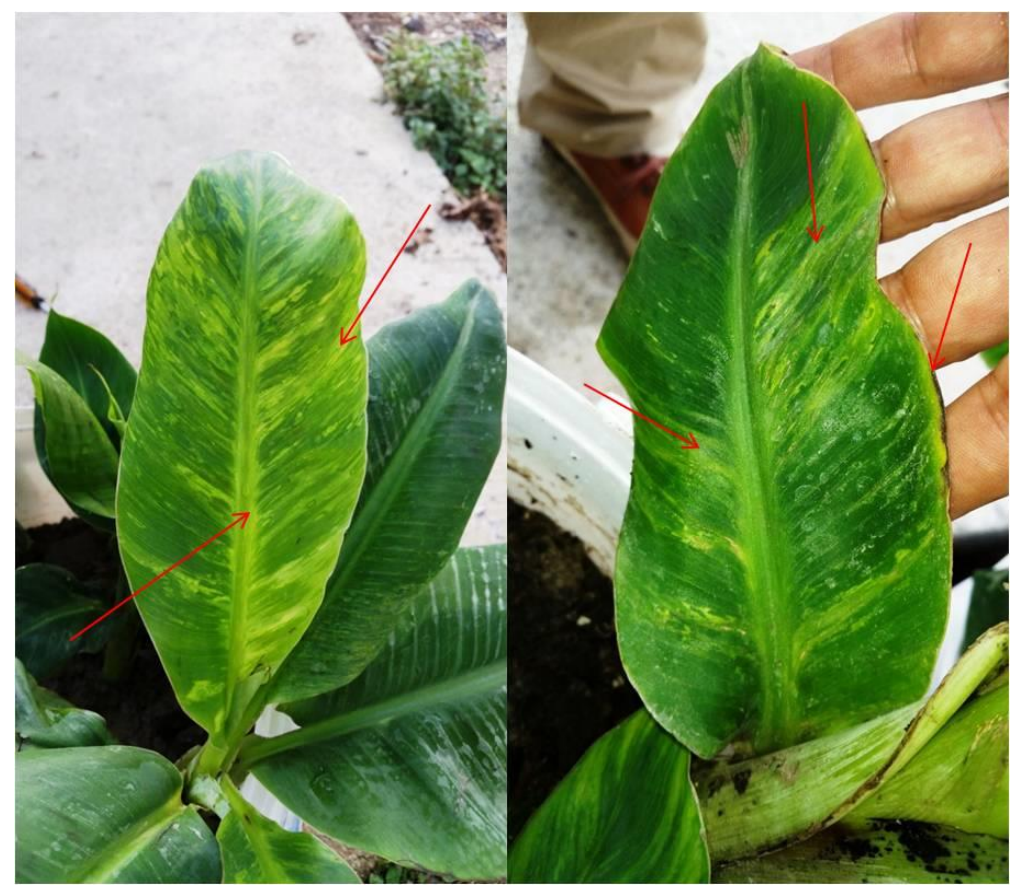

Figure 5. Leaf mosaics, streaks, marginal necrosis on banana plants

\section{Occurrence and detection of viruses by ELISA}

As a result of DAS-ELISA, positive results were obtained from CMV (Cucumber mosaic virus). While one samples gave suspected BBTV value by DAS-ELISA. In performed serological analyses, 21 out of 118 (with $17.79 \%$ incidence) tested samples produced positive reaction with the specific antiserum to CMV. However, none of the 
BBTV (Banana bunchy top virus), TMV (Tobacco mosaic tobamovirus), TSWV (Tomato spotted wilt tospovirus), PVY (Potato Y potyvirus), BCMV (Bean common mosaic potyvirus), WMV-2 (Watermelon mosaic 2 potyvirus), PRSV (Papaya ringspot virus) Potygroup and Orthotospo viruses have had strict positive reaction.

CMV is a member of the genus Cucumovirus and the family of Bromoviridae and have been reported on banana worldwide previously.

There is no commercial antiserum available to study BSV with immune test analyses. BSV can be tested with PCR analyses using DNAs obtained from banana plants.

\section{The RT-PCR amplification}

In order to verify the infection, RT-PCR analyses have been done. The target RNA regions $(\mathrm{CMV}$; 513bp and $\mathrm{BSV} ; 731 \mathrm{bp})$ on coat protein partial genes of both viruses, identical for detection, were amplified in the RT-PCR assay. The Amplified RNAs, symptomologically selected from two samples, were yielded an expected product of 513 bp (Fig. 6) on agarose gel (2\%) electrophoresis. Consequently, RT-PCR results confirmed infections of CMV in DAS-ELISA for positive plants. Additionally, $731 \mathrm{bp}$ cDNA bands of BSV, 5 samples with $4.23 \%$ incidence via PCR, were observed. A mix infection by CMV+BSV was verified among them. However, none of the samples that were tested on suspicion of BBTV symptom (Banana bunchy ball virus) did not give positive PCR reaction. Symptoms may be related to zinc deficiency.

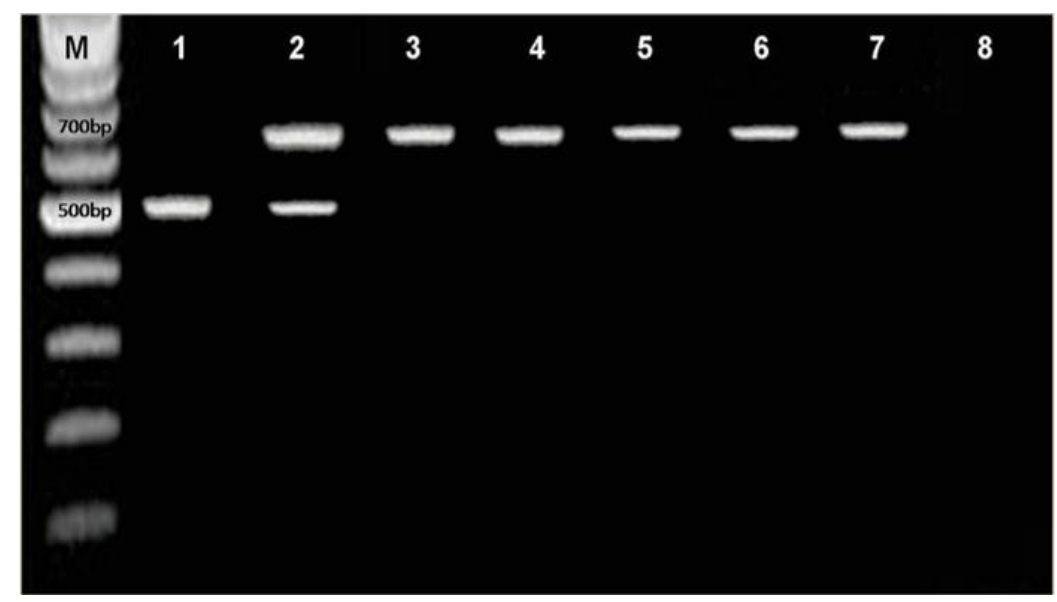

Figure 6. First lane M DNA ladder; RT-PCR product of 513 bp of CMV CP (Lane 1, Lane 2); RT-PCR product of 731 bp of BSV CP (Lane 3 to Lane 7); Also Lane 2 stand as mix infection by

$C M V+B S V$ positive samples of Musa spp. in Turkey. Lane 8 negative control on agarose gel $(2 \%)$

In the light of the observed symptoms, DAS-ELISA and PCR were conducted against nine viruses. Positive results were obtained only against CMV and BSV among all viruses (Tables 1 and 2). In addition to species specific ELISA, Potygroup and Orthotospo group specific polyclonal antiserums were not given positive results for all collected samples. 
Table 1. The sample distribution by province, presence of viruses assayed by ELISA-PCR

\begin{tabular}{c|c|c|c|c|c|c|c|c|c|c}
\hline Provinces & $\begin{array}{c}\text { Collected } \\
\text { samples }\end{array}$ & CMV & BBTV & BSV & TMV & PVY & WMMV2 & PRSV & BCMV & TSWV \\
\hline Antalya & 48 & ${\mathbf{4 8} / \mathbf{6}^{+}}^{+}$ & $48 / 0$ & ${\mathbf{4 8} / \mathbf{2}^{+}}^{+}$ & $48 / 0$ & $48 / 0$ & $48 / 0$ & $48 / 0$ & $48 / 0$ & $48 / 0$ \\
Adana & 21 & $21 / 0$ & $21 / 0$ & $21 / 0$ & $21 / 0$ & $21 / 0$ & $21 / 0$ & $21 / 0$ & $21 / 0$ & $21 / 0$ \\
Mersin & 49 & $\mathbf{4 9 / 1 5}^{+}$ & $49 / 0$ & $\mathbf{4 9 / 3}^{+}$ & $49 / 0$ & $49 / 0$ & $49 / 0$ & $49 / 0$ & $49 / 0$ & $49 / 0$ \\
Toplam & 118 & $118 / 21$ & & $118 / 5$ & & & & & & \\
\hline
\end{tabular}

+Infected samples assayed by DAS-ELISA and RT- PCR

According to DAS-ELISA and RT-PCR assays, only four major symptom types are associated with CMV and BSV (Table 2) which were recorded in Gazipaşa, Alanya and Anamur districts. All three of these districts have banana production plantains along the Mediterranean coastline of Turkey.

Table 2. Observed symptom types and test results by province in terms of CMV and BSV

\begin{tabular}{c|c|c|c|c}
\hline \multirow{2}{*}{ Provinces/districts } & \multicolumn{4}{|c}{ Symptom types } \\
\cline { 2 - 5 } & Mosaic & Chlorosis & Streaking & Necrosis \\
\hline Antalya/Gazipaşa & $11 / 2^{\mathrm{a}, \mathrm{b}}$ & $4 / 1^{\mathrm{a}, \mathrm{b}}$ & $6 / 1^{\mathrm{b}}$ & $4 / 1^{\mathrm{a}, \mathrm{b}}$ \\
Antalya/Alanya & $10 / 2^{\mathrm{a}, \mathrm{b}}$ & 3 & $7 / 1^{\mathrm{b}}$ & $3 / 1^{\mathrm{a}, \mathrm{b}}$ \\
Mersin/Anamur & $19 / 7^{\mathrm{a}, \mathrm{b}}$ & $10 / 5^{\mathrm{a}, \mathrm{b}}$ & $14 / 3^{\mathrm{b}}$ & $6 / 3^{\mathrm{a}, \mathrm{b}}$ \\
Adana & 13 & 4 & - & 4 \\
\hline
\end{tabular}

${ }^{\mathrm{a} E L I S A,}{ }^{\mathrm{b} P C R}$

\section{Phylogenetic analysis}

Sequence and phylogenetic analyses have been shown that banana CMV and pepper CMV isolates are viruses with exactly the same haplotype. Banana and pepper plants include same CMV isolate sequences (Fig. 7) and the virus isolate has spread from pepper to banana. Virus infestation may also occur mechanically or via aphid vectors.

Phylogenetic tree was performed by MEGA 7 Program and Neighbour joining method from 2 symptomologically selected banana and pepper plants. The banana sample (TRAnCMVB, accessed as new record to NCBI system with accession number: MH931390) is a Banana CMV isolate (Fig. 7; Tables 3 and 4). A different haplotype was determined by RT-PCR and sequences. The results of comparison with isolates from other countries were submitted to NCBI system as new records. The results were clarified that these isolates have similar homology with pepper CMV isolate as TRAnCMVP (accesed as new record to NCBI system with accession number: MH931391) (100\%-Turkey) and HE971674.1 pepper isolate (88\%-Tunisia); KC559757.1 melon isolate (87\% Bosnia and Herzegovina); KT270571.1 melon isolate (88\% Serbia) and KJ789892.1 squash isolates (87\% South Africa) were grouped into Ia (Fig.7; Tables 3 and 4). This result shows that the pepper and banana isolates are the same. 


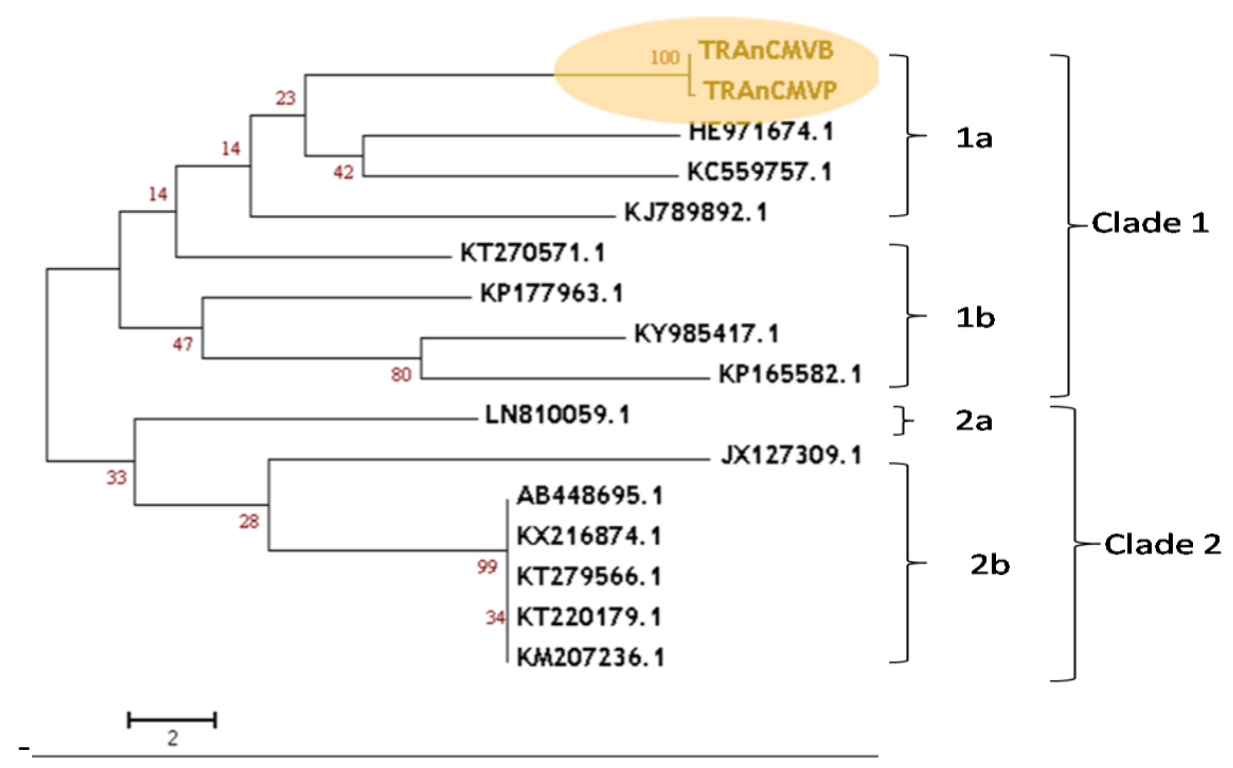

Figure 7. Phylogenetic tree of Turkish Antalya Banana CMV haplotype had branched with Group la

Another phylogenetic tree was performed by MEGA 7 Program and Neighbour joining method for one BSV banana isolates as TRAnBSV (accesed as new record to NCBI system with accession number: MH931389) (Fig. 8; Tables 5 and 6). Two different haplo group (CladeI and CladeII) were determined by sequences. This different isolate was compared with the isolates of other countries. Their results were submitted to the NCBI system as new records. The results were clarified that this isolate have similar CladeIb homology with AM905905.1 (97\% - Kenya) and KU759865.1 (98\% - Democratic Republic of Congo).

Table 3. Phylogenetic tree pair wise distance matrix of CMV haplotypes of different countries and Turkish CMV banana and pepper isolates from Antalya

\begin{tabular}{c|c|c|c|c|c|c|c|c|c|c|c|c|c|c|c}
\hline TRAnCMVB & 0.02 & 17.80 & 21.69 & 16.41 & 27.88 & 17.58 & 30.79 & 27.83 & 27.91 & 19.46 & 30.15 & 27.83 & 18.86 & 17.98 & 27.92 \\
\hline TRAnCMVP & & 17.36 & 27.12 & 15.97 & 27.35 & 17.40 & 31.03 & 27.31 & 27.32 & 19.13 & 30.47 & 27.31 & 19.32 & 17.80 & 27.40 \\
\hline HE971674.1 & & & 28.78 & 21.62 & 26.67 & 17.83 & 26.74 & 26.62 & 26.71 & 27.18 & 17.74 & 26.62 & 15.71 & 14.73 & 26.67 \\
\hline KY985417.1 & & & & 17.39 & 27.12 & 21.13 & 18.17 & 27.17 & 27.08 & 16.85 & 11.51 & 27.17 & 20.22 & 18.83 & 27.12 \\
\hline JX127309.1 & & & & & 15.89 & 29.98 & 26.36 & 15.89 & 15.89 & 17.98 & 21.40 & 15.89 & 26.41 & 20.46 & 15.86 \\
\hline KX216874.1 & & & & & & 18.86 & 15.67 & 0.01 & 0.00 & 21.50 & 28.49 & 0.01 & 26.29 & 27.96 & 0.00 \\
\hline KT270571.1 & & & & & & & 20.12 & 18.86 & 18.83 & 18.65 & 18.95 & 18.86 & 16.34 & 21.54 & 18.83 \\
\hline LN810059.1 & & & & & & & 15.67 & 15.67 & 20.18 & 32.96 & 15.67 & 17.70 & 18.68 & 15.67 \\
\hline KT220179.1 & & & & & & & & & 0.01 & 21.50 & 28.44 & 0.00 & 26.24 & 27.91 & 0.01 \\
\hline KT279566.1 & & & & & & & & & 21.48 & 28.52 & 0.01 & 26.29 & 27.92 & 0.01 \\
\hline KP177963.1 & & & & & & & & & & & 17.42 & 21.50 & 20.11 & 21.53 & 21.47 \\
KP165582.1 & & & & & & & & & & & & 28.44 & 19.62 & 26.11 & 28.44 \\
\hline KM207236.1 & & & & & & & & & & & & & 26.24 & 27.91 & 0.01 \\
\hline KJ789892.1 & & & & & & & & & & & & & & 20.65 & 26.29 \\
\hline KC559757.1 & & & & & & & & & & & & & & & 27.96 \\
\hline
\end{tabular}


Fidan - Koç: Occurrence, ecology and phylogeny of banana streak badnavirus (BSV) and cucumber mosaic cucumovirus (CMV) in Musa sp. production areas of the Mediterranean coastline of Turkey - 5945 -

Table 4. The isolates which are listed in phylogenetic tree with Turkey Banana CMV isolate

\begin{tabular}{c|c|c|c}
\hline Bootstrap code & Origin & Host & Identity \% \\
\hline TRAnCMVP & Anamur/Turkey & Capsicum annuum & 100 \\
TRAnCMVB & Anamur/Turkey & Banana & 100 \\
\hline HE971674.1 & Tunisia & Capsicum annuum & 88 \\
\hline KY985417.1 & Macedonia & Capsicum annuum & 88 \\
\hline JX127309.1 & Serbia & Solanum lycopersicum (Tomato) & 88 \\
KX216874.1 & Democratic Republic of the Congo & Musa acuminata & 87 \\
\hline KT270571.1 & Serbia & Cucumis melo & 87 \\
KT279566.1 & Iran & Cucumber & 87 \\
LN810059.1 & Greece-Lesvos & Citrullus lanatus & 87 \\
KT220179.1 & Egypt & Banana & 87 \\
KP177963.1 & India & & 87 \\
KP165582.1 & Germany & Canna generalis Cv. Allengheny & 87 \\
KM207236.1 & Egypt-Giza, Governorate & Tomato & 87 \\
KJ789892.1 & South Africa & Cucurbita pepo L & 87 \\
KC559757.1 & Bosnia and Herzegovina & Cucumis melo (Melon & 87 \\
AB448695.1 & Syria-Hama & Solanum tuberosum & 87 \\
\hline
\end{tabular}

Table 5. Phylogenetic tree pair wise distance matrix of BSV haplotypes of different countries and Turkish BSV banana and pepper isolates from Antalya

\begin{tabular}{|l|l|l|l|l|l|l|l|l|l|l|l|l|l}
\hline TRAnBSV & 4.02 & 6.26 & 4.06 & 5.76 & 5.91 & 4.39 & 4.71 & 4.44 & 5.84 & 7.07 & 4.10 & 3.76 & 6.33 \\
\hline KJ013506.1 & & 1.74 & 0.02 & 5.93 & 5.95 & 4.70 & 3.89 & 4.07 & 5.74 & 4.42 & 4.45 & 3.70 & 6.06 \\
\hline DQ859899.1 & & & 1.84 & 4.24 & 4.29 & 4.41 & 4.02 & 3.57 & 4.18 & 3.91 & 4.39 & 3.61 & 3.68 \\
\hline AJ002234.1 & & & & 6.03 & 6.05 & 4.70 & 4.04 & 4.03 & 5.86 & 4.55 & 4.47 & 3.57 & 5.91 \\
\hline KF545102.1 & & & & & 0.05 & 6.30 & 6.08 & 4.28 & 0.08 & 4.28 & 6.14 & 3.63 & 4.69 \\
\hline KF545124.1 & & & & & & 6.18 & 6.14 & 4.27 & 0.11 & 4.32 & 6.18 & 3.74 & 4.62 \\
\hline JQ346523.1 & & & & & & & 3.99 & 3.83 & 6.14 & 5.88 & 5.72 & 3.52 & 3.83 \\
\hline FJ594909.1 & & & & & & & & 3.35 & 5.86 & 4.08 & 4.35 & 3.91 & 4.63 \\
\hline EU076424.1 & & & & & & & & & 4.23 & 4.24 & 3.82 & 2.65 & 3.92 \\
\hline KF545103.1 & & & & & & & & & & 4.40 & 5.88 & 3.64 & 4.68 \\
\hline KT339346.1 & & & & & & & & & & & 4.20 & 4.17 & 5.72 \\
\hline AM905905.1 & & & & & & & & & & & & 3.93 & 5.82 \\
\hline KU759865.1 & & & & & & & & & & & & & 4.15 \\
AF215816.1 & & & & & & & & & & & & & \\
\hline
\end{tabular}

Table 6. The isolates which are listed in Phylogenetic tree with Turkish Banana BSV isolate

\begin{tabular}{|c|c|c|c|}
\hline Bootstrap code & Origin & Host & Identity \% \\
\hline TSAnBSV & Turkey-Anamur & Banana & \\
\hline KJ013506.1 & France: Montpellier & " & 97 \\
\hline DQ859899.1 & India & $"$ & 97 \\
\hline AJ002234.1 & Nigerian & $"$ & 97 \\
\hline KF545124.1 & Uganda & $"$ & 97 \\
\hline KF545103.1 & Tanzania & $"$ & 93 \\
\hline KT339346.1 & China: Guangzhou & $"$ & 97 \\
\hline KF545102.1 & Kenya & $"$ & 97 \\
\hline JQ346523.1 & India & $"$ & 98 \\
\hline FJ594909.1 & South China & $"$ & 98 \\
\hline EU076424.1 & Colombia & $"$ & 99 \\
\hline AF215816.1 & Australia: N. Queensland & $"$ & 97 \\
\hline KF548092.1 & Brazil & $"$ & 98 \\
\hline AM905905.1 & Kenya & $"$ & 97 \\
\hline KU759865.1 & Dem. Rep. of the Congo & $"$ & 98 \\
\hline
\end{tabular}




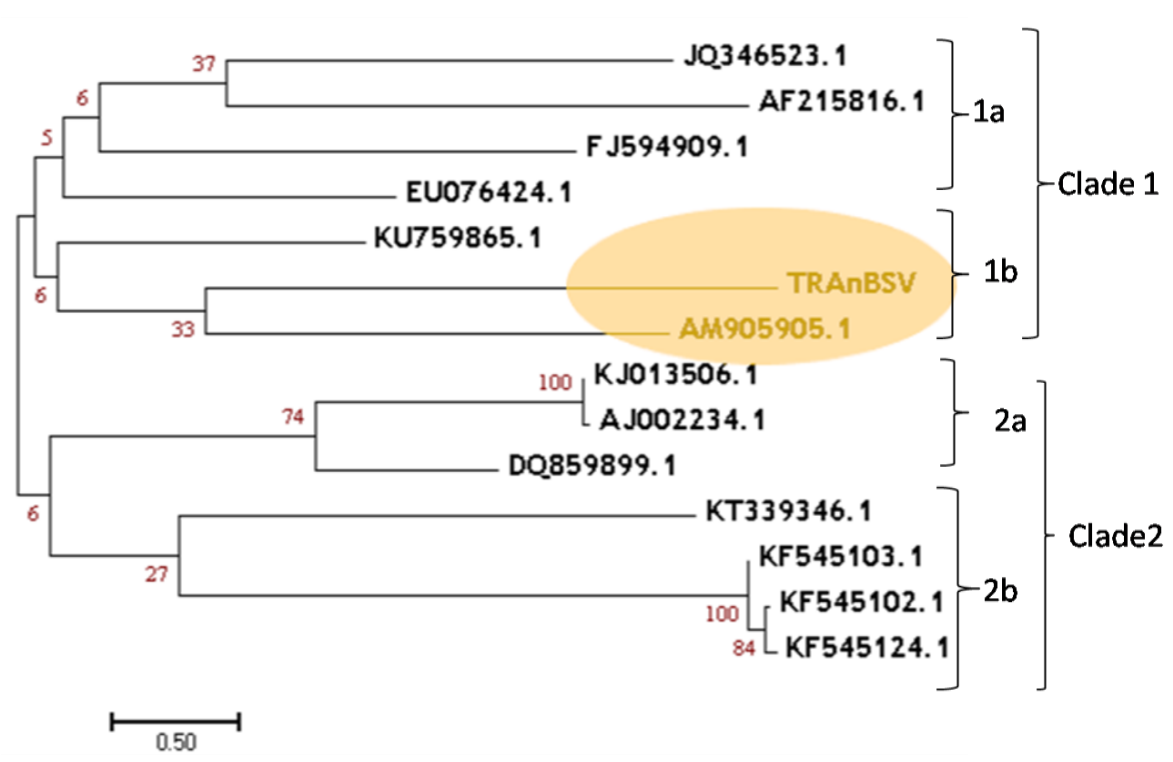

Figure 8. Phylogenetic tree of Turkish Antalya Banana BSV haplotype had branched with Group $1 b$

\section{Discussion}

The Mediterranean coast line is an important agricultural production area and all kind of commercial ships are visiting for trade. This study revealed the natural distribution and occurrence of banana viruses in this area. Our results pointed out that the sanitary conditions in banana growing fields are very important in Turkey to prevent the spreading of common plant viruses. CMV is the most widely spread virus, infecting banana crops in Turkey, it belongs to the genus Cucumovirus and it is transmitted by aphids. Management of these vectors are difficult. The symptoms on collected plants have been assigned to CMV and BSV by mixed infection. CMV infection causes typical leaf mosaic symptoms, mosaic may become necrotic when mixed infection occurs with BanMMV or BSV (Teycheney et al., 2005). These results fit with our results where our collected samples from Antalya samples generally showed a severe mosaic and became necrotic, when had CMV mixed infection with Banana streak mosaic virus (BSV). Similarly, Daniells et al. (2001) pointed out BSV infection have caused yield losses and severe mosaic symptoms. Discrete dark spots may appear on the petiole of the infected plants, pseudostem splitting, fruit bunch emerges from pseudostem, cracks on the skin of fruits occur, which become impossible to commercialize (Teycheney et al., 2005). The most characteristic symptoms of BSV infection are chlorotic and necrotic streaks on the leaves which have been recorded from Turkey BSV banana isolates by Lockhart and Jones (1999). Severe symptoms are correlated with high virus titres (Dahal et al., 1998a, b; 1999). With increasing concern about BSV, there is relatively little information on the effect of virus infection on yield of bananas. In one study in the Ivory Coast, the reduction in yield of cv. Poyo bananas (Musa spp. AAA group, Cavendish subgroup) was estimated to be from $7 \%$ to $90 \%$, depending on the severity of symptoms (Lassoudière, 1974). Banana streak infections (BSVs) involve a complex of badnaviruses from the family Caulimoviridae known to contaminate Musa sp. around the world (Bhat et al., 2016). 
The study was focused on BSV due to first occurrence on banana, cultivated in Turkey; Although BSV has a narrower host range than CMV, the BSV may survive in various banana plantains that are imported materials and cuttings as a reservoir. In addition, the presence of vector mealybug in the greenhouse and outside, and the lack of biological and chemical control agents, increase the risk of infection. These results allow CMV to be spread more by aphids from cultivated vegetable crops such as; pepper, melon, squash, tomatoes, are cultivated by farmers in the local area or near the banana greenhouse to meet household consumption need. It also originates progressively from different weed species and occurs after infection with infected seedlings or inoculum sources. Previous studies have found CMV in Turkey (Y1lmaz, 1976). The destructive effect of CMV on Turkish banana production has been detailed by same researcher. If It's not well controlled. The current results have verified the previous results that banana plants infected with CMV could be limiting banana production. But overall, CMV has a low impact on production as it can be well controlled (Teycheney et al., 2005)

This is the first report of BSV and BSV+CMV mix infection infected banana in the Eastern Mediterranean Coastline of Turkey. Also it confirms reliable laboratory molecular methods that previous reports include of CMV on banana using serological, symptomologicaly and biological indexing in Turkey by Y1lmaz (1976), Sertkaya (2016) and Tohumcu and Kamberoğlu (2018). BSV have been transmitted not only by mealy bug but also by sucker. Also tissue culture propagation has an importance. It can cause major economic yield loss. Eradication, Certified Material and Vector Management are important strategies to overcome the BSV.

In Cuba, Higginson et al. (2016) focused on some BSV strains on tetraploid banana cvs. FHIA 23. Banana leaf tests were gathered at arbitrary from symptomatic or potentially non-symptomatic plants in four FHIA 23 plots situated in El Mambí in Ciego de Avila area, Bayamo in Granma, Quivicán in Mayabeque and Santo Domingo in Villa Clara areas. Gathered samples were prepared and recorded for the nearness of BSV species BSOLV, BSGFV, and BSIMV by multiplex immunocapture PCR (MICPCR), An aggregate of 84 tests were gathered. Just a single plant at El Mambí was symptomatic with indications comprising of slight chlorotic leaf streaks. While BSOLV and BSGFV species were recognized in $12 \%$ of the 84 filed FHIA 23 tests, the species BSIMV did not show up in any example of this cultivar. Contaminated FHIA 23 tests were just recognized in the eight-month manor of El Mambí in Ciego de Avila. 17\% $(9 / 52)$ of the examples were distinguished contaminated by BSOLV in this area, including the plant showing chlorotic leaf streaking. An extra FHIA 23 nonsymptomatic example of the same area was contaminated by BSGFV.

We have hypothesized that the BSV might come with ornamental plants which are relatives of banana plants. It is not able to coincidence that the BSV appeared in the banana grown area which is also a very popular place for the ornamental plants at the Eastern Mediterranean Coastline of Turkey. The CMV is commonly seen all over vegetable and fruit grown regions. Our results have clearly indicated that the virus could come from vegetable grown areas to banana grown places.

Bunchy top symptoms can be recorded on young suckers Infected plants are dwarfed and their emerging leaves are small and narrow with brittle, yellow edges. The leaves grow upright and have a stunted, bunched appearance similarly to the results of Teycheney et al. (2005). But there is no obvious result from ELISA and symptomologically suspected samples against Banana bunchy top virus in Turkey. 
This paper also indicates that uncontrolled distribution of Banana plants in countries will create the viral problems.

The PCR technique was standardized and successfully applied for CMV and BSV detection. PCR-based detection methods will have the advantage of amplifying the target nucleic acid present even at very low level and it is an attractive technique for the early diagnosis of plant viral agents (Mahadev et al., 2013). Sison et al. (2017) reported four episomal BSV species either in single or mixed infections in the Philippines by Moleculer assays.

Molecular analyses have distinguished that there is one CMV haplotype present in Turkey according to their sequences alignments at NCBI system. Sequence alignments have shown Turkey's banana CMV haplotypes (TRAnCMVB) have similar homology with pepper CMV isolate from Turkey as TRAnCMVP and HE971674.1 pepper isolate from Tunisia; KC559757.1 melon isolate from Bosnia and Herzegovina; KT270571.1 melon isolate from Serbia (that could have same origin with Bosnia And Herzegovina) and KJ789892.1 squash isolates from South Africa clustered into Ia although isolates belong to different geographic origins.

To verify BSV banana isolate as TRAnBSV two different haplo group (CladeI and CladeII) were determined by sequences. Results were submitted to the NCBI system as new records, were clarified that this isolate have similar CladeIb homology with AM905905.1 from Kenya and KU759865.1 from Democratic Republic of the Congo. It is concluded that as evidence by phylogenetic analysis, both all CMV and BSV isolates are not identified as belong to new population or groups.

Both CMV and BSV Turkish isolates which are focused on in this study, have been placed to the NCBI system with new accession numbers (NCBI, 2018).

The results have indicated that all exported plant materials can be distributed through any quarantine regulation.

\section{Conclusion}

Further studies should be planned for identifying respective vectors and unknown epidemiological features and characteristics of the viruses (Islam et al, 2016). There are new viruses perpetuating in weeds and adjacent crop species in plantains. Novel management strategies for diseases will be devised upon these studies to protect sanitized and resistant plants, often depends on the virulence of pathogen (Razukas et al., 2007). Therefore, the infection pathway and transmissibility of major viruses could be prevented. This can be done by determining the virus ecology and molecular origin, which were another outcome of this study.

Thomas et al. (2015) description of virus diseases emerging from mass spread of contaminated plant materials or from mealybug transmission from neighbouring contaminated plants is obscure. Regardless, it is important to perform more precise and valid analytical strategies to screen the condition of planting material. On the off chance that in vitro culture is utilized, the meristem micropropagation joined with cryotherapy methods will guarantee the evacuation of tainting infections. Sison et al. (2017) determined some preventions, such as host resistance and removal of infected plants, against BSV infections are suitable control practices.

Banana bunchy top virus (BBTV), banana streak virus (BSVs) and cucumber mosaic (CMV) infections are announced to be contaminating bananas habitually all around the world. Successful control of their spread relies upon strong discovery of these infections 
in engendering stock, planting material, contaminated nursery plants, and through strict quarantine Zhang et al. (2018).

Tripathi et al. (2019), reported a strategy to inactivate the eBSV by editing the virus sequences, named as CRISPR/Cas9 is a novel approach, as well as editing of endogenous banana streak virus in the B genome of Musa spp. Seventy-five percent of the altered plants stayed asymptomatic in contrast with the non-altered control plants. This examination prepares for the improvement of B genome germplasm and its utilization in rearing projects to deliver cross breeds that can be comprehensively spread.

All positive samples detected in this study, have been eradicated. Thus, it was tried to maintain or protect the country's disease free status with the definite destruction of the sources of infection, which were detected on a limited or limited level to comply with agricultural quarantine legal measures.

This report is the primary step to initiate research on the impact of the virus in banana production and germplasm exchange.

Acknowledgements. Thanks to Assoc.Prof. Ozer Çalış and Prof.Dr.Nedim Mutlu for critical review of the publication.

Conflict of interests. The authors declare that they have no conflict of interests.

Ethical approval. This article does not contain any studies with human participants or animals performed by any of the authors.

\section{REFERENCES}

[1] Baggaley, K. (2017): The world's bananas are under attack. But no, they're not about to go extinct. - Environment 13 September. https://www.popsci.com/worlds-bananas-underattack-disease.

[2] Bhat, A. I., Hohn, T., Selvarajan, R. (2016): Badnaviruses: the current global scenario. Viruses 8: 177.

[3] Buzkan, N., Yüzer, D. (2009): Molecular detection of seed-borne viruses in Kahramanmaras red peppers. - Alatarım 8(1): 1-7.

[4] Cherian, A. K., Baranwal, V. K., Malathi, V. G., Pant, R, P., Ahlawat., Y. S. (2004): Banana streak virus from India and its detection by polymerase chain reaction. - Indian Journal of Biotechnology 3: 409-413.

[5] Clark, M. F., Adams, A. N. (1977): Characteristic of microplate method of enzymelinked immunosorbent assay for detection of plant viruses. - J. Gen. Virol. 34: 475-483.

[6] Dahal, G., Hughes, J. d. A., Thottappilly, G., Lockhart, B. E. L. (1998a): Effect of temperature on symptom expression and reliability of banana streak badnavirus detection in naturally infected plantain and banana (Musa spp.). - Plant Disease 82: 16-21.

[7] Dahal, G., Pasberg-Gauhl, C., Gauhl, F., Thottappilly, G., Hughes, J. d. A. (1998b): Studies on a Nigerian isolate of banana streak badnavirus: II. Effect of intraplant variation on virus accumulation and reliability of diagnosis by ELISA. - Annals of Applied Biology 132: 263-275.

[8] Dahal, G., Gauhl, F., Pasberg-Gauhl, C., Hughes, J., d. A., Thottappilly, G., Lockhart, B. E. L. (1999): Evaluation of micropropagated plantain and banana (Musa spp.) for banana streak badnavirus incidence under field and screenhouse conditions in Nigeria. - Ann. Appl. Biol. 134: 181-191. 
[9] Daniells, J. W., Geering, A. W. D., Bryde, N. J., Thomas, J. E., Ferguson, M. E. (2001): The effect of Banana streak virus on the growth and yield of dessert bananas in tropical Australia. - Ann Appl Biol 139: 51-60.

[10] Dellaporta, S. L., Wood, J., Hicks, J. B. (1983): A plant DNA mini-preparation: version 2. - Plant Mol Biol Rep 1(4): 19-21. DOI: 10.1007/BF02712670.

[11] FAO Data (2015): Food and Agriculture Organization of the United Nations. The Statistics Division of FAO. - http://faostat.fao.org/.

[12] Gambley, C. F., Thomas, J. E. (2001): Molecular characterization of banana mild mosaic virus, a new filamentous virus in Musa spp. - Arch. Virol. 146: 1369-1379.

[13] Higginson, E. J., Font, C., Quiala, I., Gonzalez, G., Fonseca, M. A., Echemendía, A. L., Teycheney, P. Y. (2016): Presence of banana streak viruses on the cultivar FHIA 23 in Cuba. - Fitosanidad 20(2): 93-94.

[14] Islam, W., Zhang, J., Adnan, M., Noman, A., Zaynab, M., Wu, Z. (2016): Plant virus ecology: a glimpse of recent accomplishments. - Applied Ecology And Environmental Research 15(1): 691-705.

[15] Karanfil, A., Soylu, B., Korkmaz, S. G. (2016): Çanakkale İli ve İlçelerindeki Soğanlı Süs Bitkilerinde Hiyar Mozaik Virüsü (Cucumber mosaic virüs; CMV) Enfeksiyonunun Araştırılması, Turkey. - 6th Plant Protection Congress with International Participation September 5-8, 2016 Konya, Turkey.

[16] Koç, G., Fidan, H., Baloğlu, S. (2016): Zinnia elegans, Türkiye de Cucumber mosaic virus (CMV) için Bir Ara Konukçu Turkey. - 6th Plant Protection Congress with International Participation September 5-8, 2016 Konya, Turkey.

[17] Lassoudière, A. (1974): La mosaïque dite "à tirets" du bananier Poyo en Côte d'Ivoire. Fruits 29: 349-357.

[18] Lockhart, B. E. L., Jones, D. R. (1999): Banana Streak. - In: Jones, D. R. (ed.) Diseases of Banana, Abaca and Enset. CABI, Wallingford, UK, pp. 263-274.

[19] Lockhart, B. E. L., Olszewski, N. E. (1993): Serological and Genomic Heterogeneity of Banana Streak Badnavirus: Implications for Virus Detection in Musa Germplasm. - In: Ganry, J. (ed.) Breeding Banana and Plantain for Resistance to Diseases and Pests. International Network for the Improvement of Banana and Plantain, Montpellier, France, pp. 105-113.

[20] Mahadev, S. R., Thamilarasan, S. K., Kathithachalam, A. (2013): PCR detection of banana bunchy top virus (BBTV) at tissue culture level for the production of virus-free planting materials. - International Research Journal of Biological Sciences 2(6): 22-26.

[21] Meyer, J. B., Kasdorf, G. G. F., Nel, L. H., Pietersen, G. (2008): Transmission of activated episomal Banana streak OL (badna) virus (BSOLV) to cv. Williams banana (Musa sp.) by three mealybug species. - Plant Dis. 92: 1158-1163.

[22] NCBI (2018): Submissions to GenBank/Bankit. - The National Center for Biotechnology Information. https://www.ncbi.nlm.nih.gov/WebSub/?tool=genbank.

[23] Razukas, A., Jundulas, J., Asakavıciute, R. (2007): Potato cultivars susceptibility to potato late blight (Phytopthtora infestans). - Applied Ecology And Environmental Research 6(1): 95-106.

[24] Saitou, N., Nei, M. (1987): The neighbor-joining method-a new method for reconstructing phylogenetic trees. - Mol Biol Evol 4: 406-425.

[25] Sambrook, J., Fritschi, E. F., Maniatis, T. (1989): Molecular Cloning: A Laboratory Manual. - Cold Spring Harbor Laboratory Press, New York.

[26] Sertkaya, G. (2016): Hatay ilinde Muz Yetiştiriciliğinin Durumu ve Muz Bitkilerinde CMV (Cucumber mosaic virüs) nin Araştırılmas1, Turkey. - 6th Plant Protection Congress with International Participation September 5-8, 2016 Konya, Turkey.

[27] Sison, M. L. J., Cueva, F. M. D, Pozon, A. P. M. (2017): Transmission of episomal banana streak virus by mealybugs of different host plants. - J. ISSAAS 23(2): 203-214.

[28] Su, H. J. (1998): First Occurrence of Banana Streak Badnavirus and Studies on Its Vectorship in Taiwan. - In: Frison, E. A., Sharrock, S. L. (eds.) Banana Streak Virus: A 
Unique Virus-Musa Interaction? Proc. Workshop Promusa Virology Working Group. INIBAP, Montpellier, pp. 20-25.

[29] Tamura, K., Peterson, D., Peterson, N., Stecher, G., Nei, M., Kumar, S. (2011): MEGA5: Molecular evolutionary genetics analysis using maximum likelihood, evolutionary distance and maximum parsimony methods. - Mol. Biol. Evol. 28: 2731-2739.

[30] Teycheney, P. Y., Lescot, T. (2004): Viral Diseases of Banana and Plantain. - CIRAD, Montpellier.

[31] Teycheney, P. Y., Marais, A., Savanella-Dumas, L., Dulucq, M. J., Candresse, T. (2005): Molecular characterization of banana virus X (BVX) a novel member of Flexiviridae family. - Arch Virol 150: 1715-1727. DOI: 10.1007/s00705-005-0567-0.

[32] Thomas, J. E. (2015): MusaNet Technical Guidelines for the Safe Movement of Musa Germplasm, 3rd Ed. - Bioversity International, Italy, Rome.

[33] Tohumcu, E., Kamberoğlu, A. M. (2018): Türkiye'de muz üretim alanlarında Cucumber mozaik virüs (CMV)'ün RT-PCR tekniği ile teşhisi. - Türkiye VII. Bitki Koruma Kongresi.

[34] Tripathi, J. N., Ntui, V. O., Ron, M., Muiruri, S. K., Britt, A., Tripathi, L. (2019): CRISPR/Cas9 editing of endogenous banana streak virus in the B genome of Musa spp. overcomes a major challenge in banana breeding. - Communications Biology 2: 46. https://doi.org/10.1038/s42003-019-0288-7.

[35] Tripathi, S., Patil, B. L., Verma, R. (2016): Viral Diseases of Banana and Their Management. - In: Gaur, R. et al. (eds.) Plant Viruses: Evolution and Management. Springer, Singapore, pp. 289-308.

[36] TUIK (2017): Türkiye İstatistik Kurumu Haber Bülteni, Bitkisel Üretim 2. Tahmini. 2017 Say1: 2458327 Ekim 2017.

[37] Yılmaz, M. A. (1976): Akdeniz Bölgesinde Muzlarda Muz Mozaik Virüsü ve Özçürüklügü Yapan Fungal Etmenler Üzerine Araştirmalar. - Ç. Ü. Ziraat Fakültesi Bitki Koruma Bölümü Doçentlik Tezi.

[38] Zhang, J., Borth, W., Lin, B., Melzer, M., Shen, H., Pu, X., Sun, D., Nelson, S., Hu, J. (2018): Multiplex detection of three banana viruses by reverse transcription loopmediated isothermal amplification (RT-LAMP). - Tropical Plant Pathology 43(6): 543551. https://doi.org/10.1007/s40858-018-0257-6. 